\title{
IDENTIFIKASI TIGA ISOLAT CENDAWAN PENGHASIL GAHARU DARI NUSA TENGGARA BARAT DENGAN MENGGUNAKAN PRIMER ITS DAN TEF 1- $\alpha$
}

Identification of three agarwood-forming fungi isolates from Nusa Tenggara Barat using ITS and TEF $1-\alpha$

\author{
Y. M. M. Anita Nugraheni ${ }^{1}$, Lutfi Anggadhania ${ }^{1}$, Riza Arief Putranto ${ }^{2}$ \\ ${ }^{1}$ Balai Penelitian Teknologi Hasil Hutan Bukan Kayu \\ Jl. Dharma Bhakti, No. 7, PO-Box 1054, Ds. Langko, Kec. Lingsar, \\ Kab. Lombok Barat, Indonesia \\ e-mail: yosephinmartha@gmail.com \\ ${ }^{2}$ Pusat Penelitian Bioteknologi dan Bioindustri Indonesia (PPBBI) \\ Jl. Taman Kencana No. 1, Bogor - Jawa Barat, Indonesia
}

Tanggal diterima : 25 Mei 2015, Tanggal direvisi : 15 Juni 2015, Disetujui terbit : 10 Agustus 2015

\begin{abstract}
Several isolates of agarwood-forming fungus in Gyrinops versteegii have been isolated from the result of exploration in Lombok and Sumbawa Islands. This study aimed to identify the three fungus associated with the agarwood formation in G. versteegii originated from Lombok Tengah, Alas, and Lombok Barat, Nusa Tenggara Barat. The three fungus cultured in liquid medium PDB (Potato Dextrose Broth) and incubated for 1 month in shaken culture. The mycelium of each fungus was harvested for DNA isolation. Amplification is done by Polymerase Chain Reaction (PCR) using the Primers ITS and TEF with obtained amplicon having base length ranging of 300-600 bs. BLAST analysis showed that the three fungus have similarity with Fusarium solani. These results were confirmed by phylogenetic tree where all fungus has genetic relationship with $F$. solani.
\end{abstract}

Keywords : $\quad$ agarwood, Gyrinops versteegii, Fusarium solani

\begin{abstract}
ABSTRAK
Gaharu telah dikenal secara luas sebagai salah satu produk hasil hutan bukan kayu unggulan karena manfaat dan nilai ekonomisnya yang cukup tinggi. Beberapa isolat cendawan pembentuk gaharu pada jenis Gyrinops versteegii telah diisolasi dari hasil eksplorasi di pulau Lombok dan Sumbawa. Penelitian ini bertujuan untuk mengidentifikasi tiga cendawan yang berasosiasi dengan pembentukan gaharu pada jenis Gyrinops versteegii asal Lombok Tengah, Alas, dan Lombok Barat, Nusa Tenggara Barat. Ketiga cendawan dibiakan dalam medium cair PDB (Potato Dextrose Broth) dan diinkubasikan selama 1 bulan sambil digojok. Miselium dari masing-masing cendawan dipanen untuk isolasi DNA. Amplifikasi dilakukan dengan Polymerase Chain Reaction (PCR) menggunakan primer ITS dan TEF dan diperoleh amplikon yang memiliki panjang berkisar 300-600 pb. Hasil analisis BLAST menunjukkan bahwa ketiga cendawan memiliki kesamaan dengan Fusarium solani. Hasil tersebut dikonfirmasi dengan pohon filogenetik dimana ketiga cendawan uji mempunyai kekerabatan dengan F. solani.
\end{abstract}

Kata kunci : gaharu, Gyrinops versteegii, Fusarium solani

\section{PENDAHULUAN}

Gaharu telah dikenal secara luas

karena manfaat dan nilai ekonomisnya yang cukup tinggi. Pembentukan gaharu tersebut dipengaruhi oleh berbagai faktor, antara lain genetik pohon penghasil gaharu, mikroba penginduksi, lingkungan, dan lamanya proses pembentukan gaharu. Terbentuknya gaharu berkaitan erat dengan gejala patologis dari pohon gaharu. Gaharu dapat terjadi saat patogen tertentu 
menginfeksi pohon penghasil gaharu. Respon pohon terhadap serangan patogen tersebut adalah dihasilkannya metabolit sekunder atau senyawa resin yang menyebabkan aroma wangi ketika dibakar (Sitepu, et al., 2011).

Mikroba yang berasosiasi dalam pembentukan gaharu pada setiap jenis pohon gaharu biasanya berlainan (Radian et al., 2007). Mohamed et al. (2010) di Malaysia dan Premalatha \& Kalra (2013) di India meneliti keragaman cendawan pada batang Aquilaria malaccensis, baik yang terinfeksi maupun yang sehat. Komposisi cendawan yang ditemukan pada kedua penelitian tersebut masuk ke dalam genus Fusarium, Trichoderma, dan Curvularia. Jalaluddin (1977) di Bangladesh berhasil mengisolasi cendawan Cytosphaera mangiferae Died dari pohon gaharu Aquilaria agallocha Roxb. Cendawan-cendawan tersebut prospektif untuk digunakan dalam teknologi bioinduksi gaharu. Bentukan gaharu yang dihasilkan dari masingmasing cendawan pembentuk gaharu beragam, selain karena faktor genetik (daya serang cendawan yang berbeda), diduga dipengaruhi juga oleh faktor kompatibilitas antara cendawan pembentuk gaharu dengan tanaman penghasil gaharu yang diserang (Turjaman et al., 2009).
Gyrinops versteegii merupakan salah satu dari beberapa jenis pohon penghasil gaharu yang prospektif karena memiliki nilai komersial dan berkualitas serta memiliki peluang pasar untuk dibudidayakan (Sumarna, 2012). Nusa Tenggara Barat merupakan salah satu daerah persebaran pohon penghasil gaharu yang didominasi oleh $G$. versteegii. Beberapa isolat cendawan pembentuk gaharu jenis tersebut telah diisolasi dari hasil eksplorasi di pulau Lombok dan Sumbawa. Berdasarkan identifikasi morfologi isolat asal Lombok Tengah, Lombok Barat dan Alas tergolong ke dalam genus Fusarium (Nugraheni et al., 2012). Genus Fusarium dicirikan secara pasti dengan makrokonidia yang berbentuk fusoid dengan sel kaki seperti tumit (Booth, 1971). Meskipun demikian, identifikasi spesies Fusarium secara morfologi sulit untuk dilakukan karena keterbatasan pengamatan secara visual. Terlebih spesies-spesies Fusarium memiliki ciri yang mirip satu sama lain.

Sudah sejak lama, teknik molekuler Polymerase Chain Reaction (PCR) digunakan dalam membantu proses identifikasi cendawan pada level spesies. Teknik tersebut diketahui memiliki kepekaan yang tinggi, cepat, dan akurat (Schoch et al., 2012) dibanding teknik morfometeri (Legiastuti \& Aminingsih, 2012). Pada famili cendawan, telah 
diketahui bahwa Internal Transcribed Spacer (ITS) merupakan daerah terkonservasi yang terletak diantara $5,8 \mathrm{~S}$, 18S dan 28S ribosomal DNA (rDNA) (Prihatini, 2012). Di antara daerah cis-tron ribosom, ITS memiliki probabilitas tertinggi untuk identifikasi secara luas spesies cendawan, dengan pembeda yang relatif jelas pada variasi inter- dan intraspesifik (Schoch et al., 2012). Selain ITS, Translation Elongation Factor $1-\alpha$ $(E F-1 \alpha)$ telah digunakan secara luas sebagai gen penanda untuk analisis kekerabatan (filogenetik) pada eukariotik (Roger et al., 1999). Kombinasi dari kedua penanda tersebut diketahui telah berhasil digunakan dalam identifikasi genus Fusarium (Arif et al., 2012; Abd-Elsalam et al., 2003; Nugroho, 2012; Sever et al., 2012; Kusuma, 2013).

Dalam penelitian ini, teknik PCR dengan primer penyandi ITS dan EF-1 $\alpha$ telah dilakukan untuk validasi jenis cendawan pembentuk gaharu terduga genus Fusarium yang diisolasi dari pohon G. versteegii asal Lombok Tengah, Lombok Barat dan Alas. Hasil analisis dalam riset ini menunjukkan bahwa teknik PCR dapat mengidentifikasi cendawan pembentuk gaharu hingga level spesies.

\section{BAHAN DAN METODE}

\section{A. Waktu dan Tempat}

Penelitian dilaksanakan pada bulan Juli - Desember 2013. Pembiakan isolat cendawan dilakukan di Laboratorium Mikrobiologi Balai Penelitian Teknologi Hasil Hutan Bukan Kayu (BPTHHBK), isolasi DNA dan analisis PCR dilakukan di Laboratorium Biologi Molekuler Pusat Penelitian Bioteknologi dan Bioindustri Indonesia (PPBBI). Sekuensing DNA dilakukan dengan mengirimkan sampel ke PT Genetika Science.

\section{B. Bahan}

Sampel cendawan diisolasi dari pohon gaharu jenis $G$. versteegii yang terinfeksi. Sampel tersebut berasal dari pulau Lombok dan Sumbawa. Dalam penelitian ini, sampel dari Lombok Tengah akan disebut sebagai Isolat 1. Sampel dari Sumbawa, Alas akan disebut sebagai Isolat 2. Sedangkan sampel dari Lombok Barat akan disebut sebagai Isolat 3. Primer yang digunakan berasal dari penelitian sebelumnya (Arif et al., 2012) dirangkum dalam Tabel 1.

\section{Metode}

\section{Pembiakan kultur}

Sampel cendawan dibiakkan pada media Potato Dextrose Agar (PDA) dan diinkubasi selama 7 hari. Setelah itu, sampel cendawan dipindahkan dalam media Potato Dextrose Broth (PDB) 
sebanyak $500 \mathrm{ml}$. Isolat dalam PDB digojok dengan kecepatan 125 rpm selama 1 bulan. Miselium dari masing-masing Tabel 1. Primer yang digunakan dalam penelitian

\begin{tabular}{|c|c|c|c|}
\hline Primer code & Primer sequence $\left(5^{\prime} \rightarrow 3^{\prime}\right)$ & Gene & $\begin{array}{l}\text { PCRproduct } \\
\text { (bp) }\end{array}$ \\
\hline Primer 1 & $\begin{array}{l}\text { ACAACTCATAACCCTGTGAACAT } \\
\text { CAGAAGTTGGGTGTTTTACGG }\end{array}$ & $\begin{array}{l}\text { ITS2- rDNA } \\
\text { subunit }\end{array}$ & 466 \\
\hline Primer 2 & $\begin{array}{l}\text { CCAGAGGACCCCCTAACTCT } \\
\text { CTCTCCAGTTGCGAGGTGTT }\end{array}$ & ITS1, ITS2 & 595 \\
\hline Primer 3 & $\begin{array}{l}\text { GGTATCGACAAGCGAACCAT } \\
\text { TAGTAGCGGGGAGTCTCGAA }\end{array}$ & TEF-1 $\alpha$ & 420 \\
\hline Primer 4 & $\begin{array}{l}\text { ATCGGCCACGTCGACTCT } \\
\text { GGCGTCTGTTGATTGTTAGC }\end{array}$ & TEF-1 $\alpha$ & 658 \\
\hline
\end{tabular}

\section{Isolasi DNA}

Isolasi DNA dilakukan dengan menggunakan metode Orozco-Castillo et al., (1994) yang telah dimodifikasi. Kualitas DNA diuji secara visual dengan menggunakan elektroforesis gel agarose $(0,8 \%)$. Kuantitas DNA diukur dengan spektrofotometer pada panjang gelombang 230, 260, dan $280 \mathrm{~nm}$.

\section{Amplifikasi fragmen ITS dan EF- 1a melalui teknik PCR}

PCR dilakukan dalam $25 \mu 1$ campuran reaksi yang mengandung DNA genomik $25 \mathrm{ng}$, primer $0.4 \mu \mathrm{M}, \mathrm{MgCl}_{2} 1,5$ mM, dNTP $200 \mathrm{mM}$ dan Taq polymerase 1 unit. Proses amplifikasi dilakukan menggunakan mesin PCR Applied Biosystem Veriti, dengan program PCR sebagai berikut: pra denaturasi $94^{\circ} \mathrm{C}$ selama 3 menit, dilanjutkan 35 siklus meliputi denaturasi $94^{\circ} \mathrm{C}$ selama 45 detik, annealing $59^{\circ} \mathrm{C}$ selama 45 detik, extension $72^{\circ} \mathrm{C}$ selama 1 menit, dan terakhir post extension $72^{\circ} \mathrm{C}$ selama 5 menit. Hasil PCR cendawan selanjutnya dipanen untuk isolasi DNA.

dianalisis dengan menggunakan

elektroforesis gel agarose $(0,8 \%)$.

\section{Analisis data sekuensing}

Sekuensing dilakukan untuk memverifikasi sekuen yang didapat dari hasil PCR dengan menggunakan jasa PT Genetika Science. Kromatogram hasil sekuensing dirubah menjadi format FASTA. Format tersebut kemudian digunakan untuk mengidentifikasi homologi sekuen produk PCR hingga tingkat spesies Fusarium pada database NCBI dengan menggunakan pendekatan analisis BLAST-n (https://blast.ncbi.nlm.nih.gov/Blast.cgi?P AGE_TYPE=BlastSearch).

\section{Rekonstruksi pohon filogenetis}

Analisis penjajaran sekuen hasil sekuensing dari produk PCR dilakukan dengan algoritma Multiple Sequence Comparison by Log-Expectation (MUSCLE) pada sekuen nukleotida (Edgar, 2004). Hasil penjajaran kemudian diatur kembali untuk menentukan zona 
terkonservasi dari sekuen nukleotida dengan mengggunakan perangkat Gblocks (Talavera \& Castresana, 2007). Konstruksi pohon filogenetis dilakukan dengan menggunakan model jarak genetis JukesCantor dengan metode Neighbor-Joining. Metode resampling menggunakan Bootstrap dengan random seed sebanyak 373.422 dan jumlah replikasi 100. Pohon konsensus akhir kemudian divisualisasikan dengan menggunakan software FigTree v.1.4.2 (University of Edinburgh, Scotland).

\section{HASIL DAN PEMBAHASAN}

\section{A. Isolasi DNA isolat cendawan asal Nusa Tenggara Barat}

Pengujian kualitas dan kuantitas DNA dari 3 (tiga) isolat cendawan dilakukan untuk menjamin tidak adanya kontaminasi protein dan polisakarida pada DNA yang diisolasi. DNA hasil isolasi disajikan pada Gambar 1. DNA hasil isolasi Isolat 2 dan 3 menunjukkan kualitas yang cukup baik dan tidak terkontaminasi yang ditandai dengan pita tunggal yang jelas, tebal dan tidak smear. Hasil pengukuran kemurnian dan konsentrasi DNA isolat cendawan disajikan pada Tabel 3. Tingkat kemurnian DNA hasil isolasi, terutama isolat 2 dan 3 cukup tinggi. Tingkat kemurnian DNA yang tinggi memiliki kisaran antara 1,8-2,0 (Sambrook \& Russell, 1989). Rasio absorbansi pada panjang gelombang 260 dan 280 (A260/280) yang berada di atas 2,0 menunjukkan adanya kontaminasi RNA, sedangkan rasio di bawah 1,8 menunjukkan adanya kontaminasi protein (Santella, 2006).

\section{B. Amplifikasi DNA ITS dan TEF-1a menggunakan teknik PCR}

Pada penelitian ini, teknik PCR telah berhasil digunakan untuk mengamplifikasi DNA dari ITS dan TEF$1 \alpha$ dari sampel DNA isolat-isolat dari Nusa Tenggara Barat (Gambar 2). Amplikon PCR memiliki panjang basa yang sesuai dengan primer yang digunakan. Primer 1-3 pada lajur 1-3, 5-6, dan 9-11 memiliki ukuran berkisar antara $300-500$ pb sedangkan primer 4 pada lajur 4, 8, dan 12 memiliki ukuran dibawah 1000 pb. Panjang basa tersebut akan divalidasi dengan menggunakan analisis sekuensing.

Kualitas pita DNA yang dihasilkan relatif jelas sehingga spesifisitas produk PCR dapat dibedakan dengan pita sekunder seperti pada lajur 4, 8 dan 12 . Primer TEF-1 $\alpha$ diketahui dapat mengamplifikasi beberapa pita sekunder pada suhu annealing yang rendah $\left(52^{\circ} \mathrm{C}\right)$. Pada penelitian ini, suhu annealing ditingkatkan menjadi $59^{\circ} \mathrm{C}$ sehingga amplikon yang dihasilkan sesuai dengan yang diharapkan. 


\section{Hasil sekuensing dari 12 amplikon produk PCR}

Hasil amplifikasi DNA ITS dan TEF-1 $\alpha$ menggunakan teknik PCR selanjutnya divalidasi dengan analisis sekuensing menggunakan jasa PT Genetika Science. Hasil yang diperoleh berupa elektroferogram (hasil analisis yang menampilkan grafik peak yang mewakili basa nukleotida hasil pembacaan mesin sequencer). Proses sekuensing dilakukan sebanyak 2 kali, yaitu secara forward dan reverse, sehingga hasil yang diperoleh juga berupa sekuen forward dan reverse.

Sekuen forward dan reverse tersebut selanjutnya digabungkan menggunakan program BioEdit sehingga diperoleh sebanyak masing-masing 12 konsensus, yaitu isolat 1,2 dan 3 menggunakan primer 1, 2, 3 dan 4. Dua belas konsensus tersebut adalah isolat1p1, isolat $1 \mathrm{p} 2$, isolat $1 \mathrm{p} 3$, isolat $1 \mathrm{p} 4$, isolat $2 \mathrm{p} 1$, isolat2p2, isolat2p3, isolat2p4, isolat $3 \mathrm{p} 1$, isolat3p2, isolat3p3, dan isolat3p4. Sekuen konsensus tersebut selanjutnya diubah ke dalam format FASTA (.txt) menggunakan program Notepad [Microsoft ${ }^{\circledR}$ Notepad].

Amplikon produk PCR hasil sekuensing menggunakan primer 1, 2, 3 dan 4 dikelompokkan sesuai primer yang digunakan, yaitu masing-masing kelompok isolat yang menggunakan primer ITS, terdiri dari isolat $1 \mathrm{p} 1$, isolat $1 \mathrm{p} 2$, isolat $2 \mathrm{p} 1$, isolat2p2, isolat $3 \mathrm{p} 1$, dan isolat3p2 yang dapat dilihat pada Gambar 3. Kelompok isolat yang menggunakan primer TEF-1 $\alpha$, terdiri dari isolat $1 \mathrm{p} 3$, isolat $1 \mathrm{p} 4$, isolat $2 \mathrm{p} 3$, isolat $2 \mathrm{p} 4, \quad$ isolat $3 \mathrm{p} 3, \quad$ dan isolat $3 \mathrm{p} 4$ (Gambar 3).

Amplikon produk PCR isolatlp1, isolat1p3, isolat1p4, isolat2p1, isolat2p3, isolat3p1, isolat3p3, dan isolat3p4 yang diperoleh memiliki panjang basa yang hampir sama dengan primer yang digunakan. Hal ini disebabkan karena pembacaan basa pada hasil penelitian ini memiliki peak yang jelas sehingga memudahkan untuk memperoleh daerah overlapping di antara kedua sekuen forward dan reverse, Amplikon produk PCR isolat1p2, isolat2p2, isolat3p2, dan isolat2p4 memiliki panjang $355 \mathrm{pb}$, lebih pendek dari primer yang digunakan (primer 2 yaitu $595 \mathrm{pb}$ dan primer 4 yaitu $658 \mathrm{pb}$ ). Hal tersebut disebabkan karena meskipun peak yang dihasilkan cukup jelas, akan tetapi panjang basa nukleotida hasil pembacaan mesin sequencer hanya berkisar $\pm 300 \mathrm{pb}$. Penelusuran identitas sekuen 3 isolat cendawan (12 amplikon PCR) tersebut selanjutnya dilakukan dengan cara mencocokkannya di dalam pangkalan data GenBank melalui program BLAST yang terdapat pada situs: http://www.ncbi.nlm.nih.gov/BLAST 


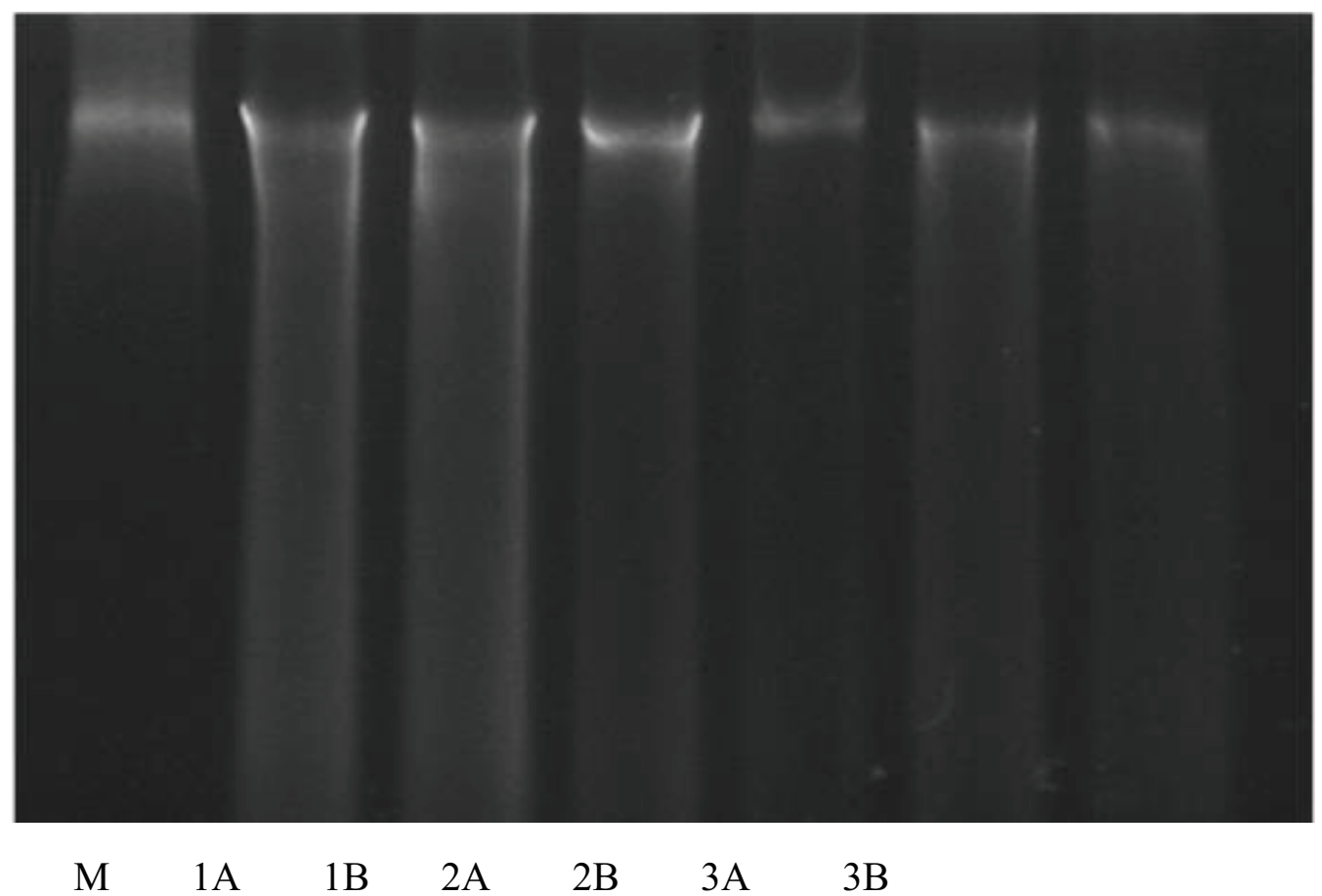

Gambar 1. Profil DNA, Isolat 1, 2 dan 3 (1000 ng). Lajur M : Marker DNA (Lamda DNA Fermentas), Lajur 1A : Isolat 1-A, Lajur 1B : Isolat 1-B, Lajur 2A : Isolat 2-A, Lajur 2B : Isolat 2-B, Lajur 3A : Isolat 3-A, Lajur 3B : Isolat 3-B

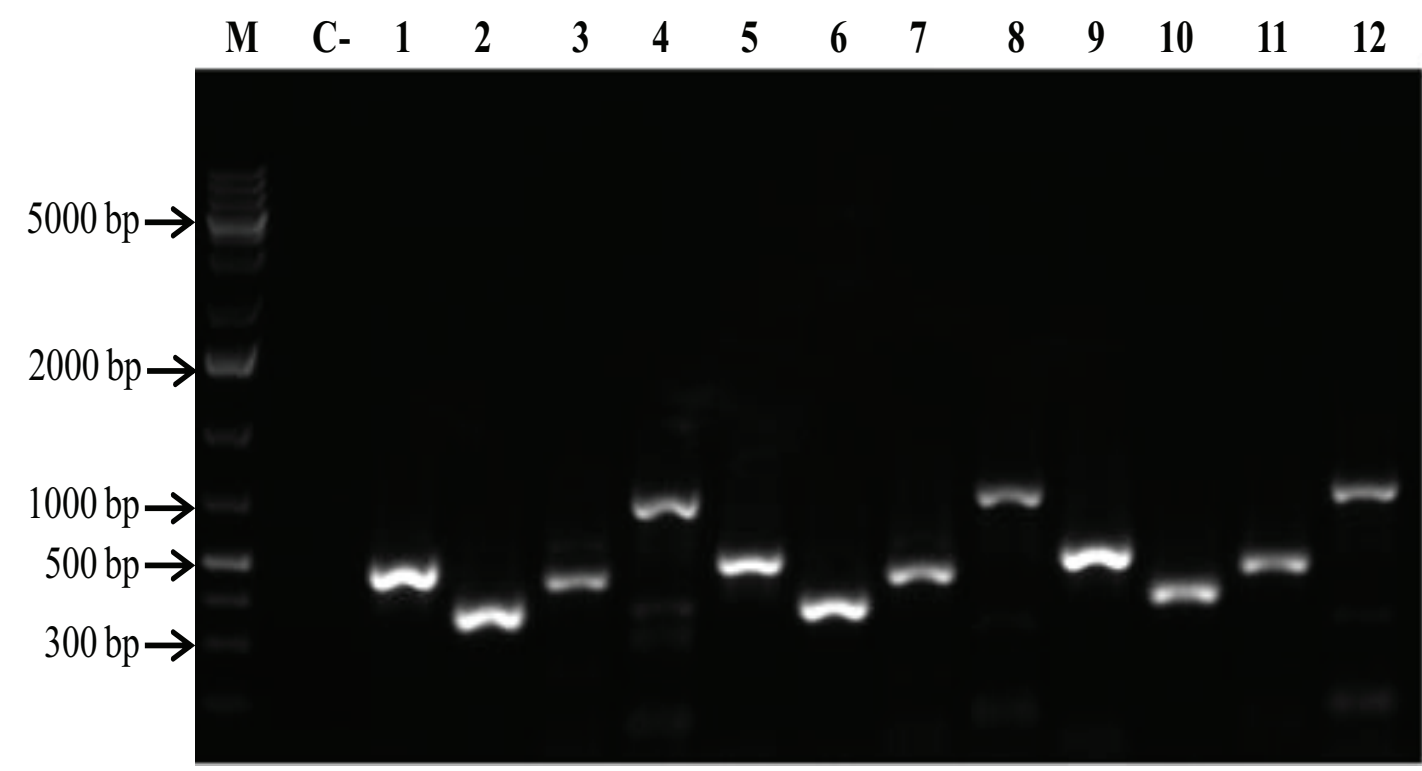

Gambar 2. Profil amplifikasi DNA untuk daerah ITS dan TEF-1 $\alpha$ isolat cendawan asal Nusa Tenggara Barat. Lajur M : Generuler $1 \mathrm{~kb}$ Plus DNA Ladder; Lajur C- : kontrol negatif $\mathrm{H}_{2} \mathrm{O}$; Lajur 1 : Isolat 1 , Primer 1 (1p1); Lajur 2 : Isolat 1, Primer 2 (1p2); Lajur 3 : Isolat 1, Primer 3 (1p3); Lajur 4 : Isolat 1, Primer 4 (1p4); Lajur 5 : Isolat 2, Primer 1 (2p1); Lajur 6 : Isolat 2, Primer 2 (2p2); Lajur 7 : Isolat 2, Primer 3 (2p3); Lajur 8 : Isolat 2, Primer 4 (2p4); Lajur 9 : Isolat 3, Primer 1 (3p1); Lajur $\underline{10}$ : Isolat 3, Primer 2 (3p2); Lajur 11 : Isolat 3, Primer 3 (3p3); Lajur 12 : Isolat 3, Primer 4 (3p4). 
Tabel 2. Kualitas dan kuantitas DNA yang diisolasi dari tiga cendawan asal Nusa Tenggara Barat.

\begin{tabular}{cccc}
\hline \multirow{2}{*}{$\begin{array}{c}\text { Kode sample } \\
\text { (sample code) }\end{array}$} & \multicolumn{2}{c}{$\begin{array}{c}\text { Rasio serapan } \\
\text { Absorbance ratio }(\mathbf{n m})\end{array}$} & $\begin{array}{c}\text { Kuantitas }(\text { Quantity }) \\
(\boldsymbol{\mu g} / \mathbf{m l})\end{array}$ \\
\cline { 2 - 3 } & $\mathbf{A 2 6 0 / 2 8 0}$ & $\mathbf{A 2 6 0 / 2 3 0}$ & 4541.5 \\
Isolat 1-A & 2.04 & 1.77 & 5077.4 \\
Isolat 1-B & 2.05 & 1.76 & 4207.3 \\
Isolat 2-A & 2.08 & 1.89 & 2317.1 \\
Isolat 2-B & 2.04 & 1.85 & 4805.5 \\
Isolat 3-A & 2.08 & 1.94 & 4826.0 \\
Isolat 3-B & 2.08 & 1.96 &
\end{tabular}

Keterangan: Perhitungan konsentrasi: A260 x $50 \mu \mathrm{g} / \mathrm{ml}$ x faktor pengenceran

\begin{abstract}
>Isolat1p1 (468 pb)
TTTACAACTCATAACCCTGTGAACATACCTAAACGTTGCTTCGGCGGGAATAGACGGCCCCGTGAAACGGGCCGCCCCCGCCAGAGGA CCCTTAACTCTGTTTCTATAATGTTTCTTCTGAGTAAAACAAGCAAATAAATTAAAACTTTCAACAACGGATCTCTTGGCTCTGGCAT CGATGAAGAACGCAGCGAAATGCGATAAGTAATGTGAATTGCAGAATTCAGTGAATCATCGAATCTTTGAACGCACATTGCGCCCGCC AGTATTCTGGCGGGCATGCCTGTTCGAGCGTCATTACAACCCTCAGGCCCCCGGGCCTGGCGTTGGGGATCGGCGGAGCCCTCTGTGG GCACACGCCGTCCCCCAAATACAGTGGCGGTCCCGCCGCAGCTTCCATCGCGTAGTAGCTAACACCTCGCGACTGGAGAGCGGCGCGG CCACGCCGTAAAACACCCAACTTCTGAA
\end{abstract}

>Isolat1p2 (355 pb)

TCCAGAGGACCCCCTAACTCTGTTTCTATAATGTTTCYTCTGAGTAAAACAAGCAAATAAATTAAAACTTTCAACAACGGATCTCTTG GCTCTGGCATCGATGAAGAACGCAGCGAAATGCGATAAGTAATGTGAATTGCAGAATTCAGTGAATCATCGAATCTTTGAACGCACAT TGCGCCCGCCAGTATTCTGGCGGGCATGCCTGTTCGAGCGTCATTACAACCCTCAGGCCCCCGGGCCTGGCGTTGGGGATCGGCGGAG CCCTCTGTGGGCACACGCCGTCCCCCAAATACAGTGGCGGTCCCGCCGCAGCTTCCATCGCGTAGTAGCTAACACCTCGCAACTGGAG AGA

>Isolat2p1 (466 pb)

TTACAACTCATAACCCTGTGAACATACCTAAACGTTGCTTCGGCGGGAATAGACGGCCCCGTAAAACGGGCCGCCCCCGCCAGAGGAC CCTTAACTCTGTTTCTATAATGTTTCTTCTGAGTAAAACAAGCAAATAAATTAAAACTTTCAACAACGGATCTCTTGGCTCTGGCATC GATGAAGAACGCAGCGAAATGCGATAAGTAATGTGAATTGCAGAATTCAGTGAATCATCGAATCTTTGAACGCACATTGCGCCCGCCA GTATTCTGGCGGGCATGCCTGTTCGAGCGTCATTACAACCCTCAGGCCCCCGGGCCTGGCGTTGGGGATCGGCGGAGCCCCCCGTGGG CACACGCCGTCCCCCAAATACAGTGGCGGTCCCGCCGCAGCTTCCATCGCGTAGTAGCTAACACCTCGCGACTGGAGAGCGGCGCGGC CACGCCGTAAAACACCCAACTTCTGA

>Isolat2p2 (355 pb)

TCCAGAGGACCCCCTAACTCTGTTTCTATAATGTTTCTTCTGAGTAAAACAAGCAAATAAATTAAAACTTTCAACAACGGATCTCTTG GCTCTGGCATCGATGAAGAACGCAGCGAAATGCGATAAGTAATGTGAATTGCAGAATTCAGTGAATCATCGAATCTTTGAACGCACAT TGCGCCCGCCAGTATTCTGGCGGGCATGCCTGTTCGAGCGTCATTACAACCCTCAGGCCCCCGGGCCTGGCGTTGGGGATCGGCGGAG CCCCCCGTGGGCACACGCCGTCCCCCAAATACAGTGGCGGTCCCGCCGCAGCTTCCATCGCGTAGTAGCTAACACCTCGCAACTGGAG AGA

>Isolat3p1 (467 pb)

TTACAACTCATAACCCTGTGAACATACCTAAACGTTGCTTCGGCGGGAATAGACGGCCCCGTWAAACGGGCCGCCCCCGCCAGAGGAC CCTTAACTCTGTTTCTATAATGTTTCTTCTGAGTAAAACAAGCAAATAAATTAAAACTTTCAACAACGGATCTCTTGGCTCTGGCATC GATGAAGAACGCAGCGAAATGCGATAAGTAATGTGAATTGCAGAATTCAGTGAATCATCGAATCTTTGAACGCACATTGCGCCCGCCA GTATTCTGGCGGGCATGCCTGTTCGAGCGTCATTACAACCCTCAGGCCCCCGGGCCTGGCGTTGGGGATCGGCGGAGCCCCCCGTGGG CACACGCCGTCCCCCAAATACAGTGGCGGTCCCGCCGCAGCTTCCATCGCGTAGTAGCTAACACCTCGCGACTGGAGAGCGGCGCGGC CACGCCGTAAAACACCCAACTTCTGAA

>Isolat3p2 (355 pb)

TCCAGAGGACCCCCTAACTCTGTTTCTATAATGTTTCTTCTGAGTAAAACAAGCAAATAAATTAAAACTTTCAACAACGGATCTCTTG GCTCTGGCATCGATGAAGAACGCAGCGAAATGCGATAAGTAATGTGAATTGCAGAATTCAGTGAATCATCGAATCTTTGAACGCACAT TGCGCCCGCCAGTATTCTGGCGGGCATGCCTGTTCGAGCGTCATTACAACCCTCAGGCCCCCGGGCCTGGCGTTGGGGATCGGCGGAG CCCCCCGTGGGCACACGCCGTCCCCCAAATACAGTGGCGGTCCCGCCGCAGCTTCCATCGCGTAGTAGCTAACACCTCGCAACTGGAG AGA

Gambar 3. Amplikon produk PCR hasil sekuensing menggunakan primer 1 dan 2 (ITS) dari isolat cendawan asal Nusa Tenggara Barat. 


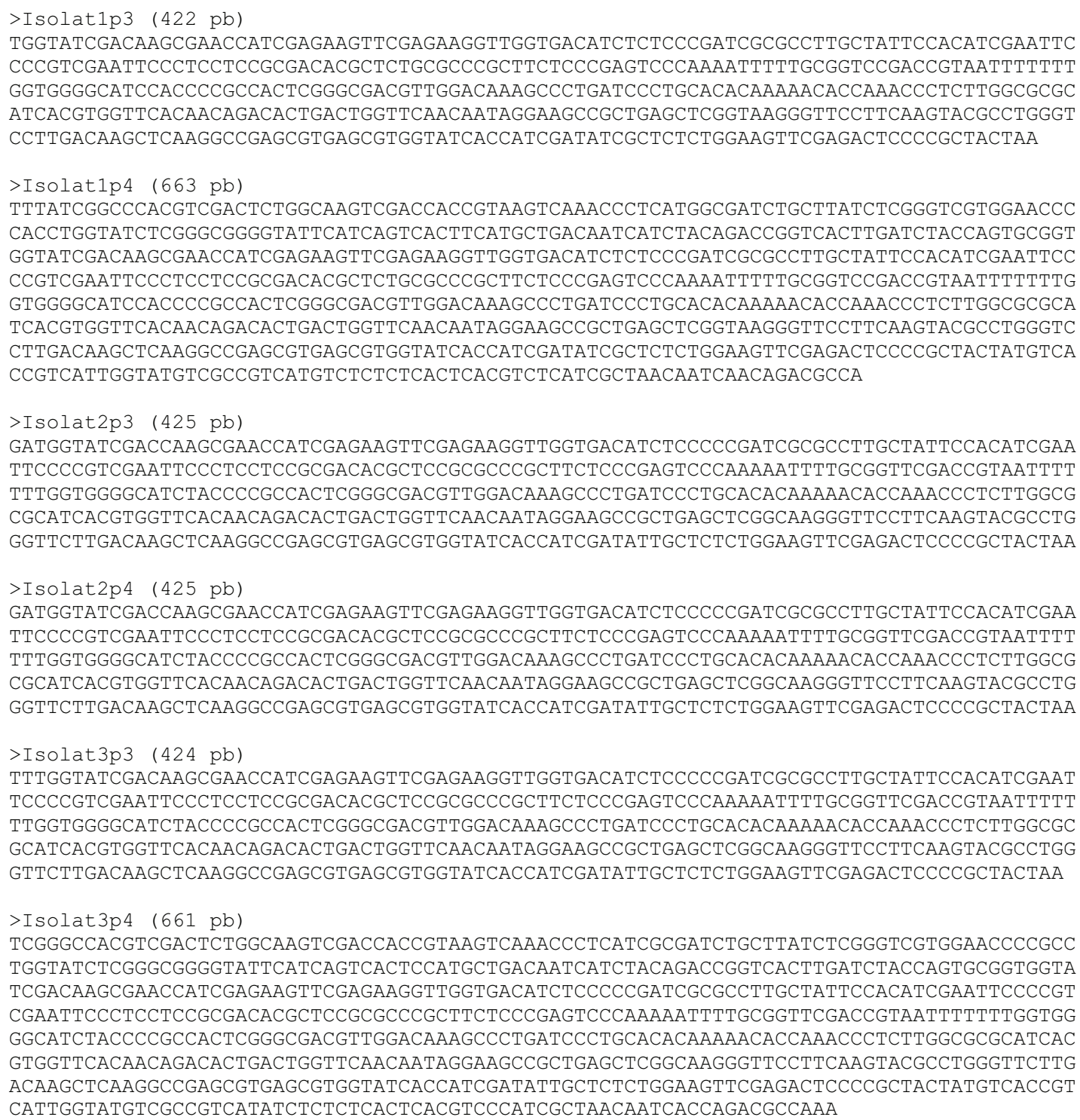

Gambar 4. Amplikon produk PCR hasil sekuensing menggunakan primer 3 dan 4 (TEF-1 $\alpha$ ) dari isolat cendawan asal Nusa Tenggara Barat.

\section{Analisis sekuen dengan menggunakan BLAST}

Hasil analisis BLAST pada 12 amplikon PCR menunjukkan kedekatan tiga isolat cendawan yang diuji dengan Fusarium solani (Tabel 3). Analisis BLAST lazim digunakan untuk mencari homologi terdekat dari sekuen query. Berdasarkan hasil tersebut, diketahui bahwa tiga isolat Fusarium yang dianalisis tergolong pada spesies $F$. solani dengan persentase kemiripan sebesar 98-99\%. Meskipun kedua isolat yang diidentifikasi memiliki jenis yang sama, yaitu sama-sama $F$. solani, akan tetapi terdapat perbedaan pada hasil inokulasi kedua isolat tersebut di Lombok Barat. Perbedaan ini dimungkinkan terjadi karena dipengaruhi 
oleh beberapa faktor, antara lain adalah faktor genetik inang, faktor kondisi lingkungan, faktor genetik $F$. solani, serta kesesuaian dan interaksi antara beberapa faktor tersebut. Menurut Santoso et al., (2012), berdasarkan identifikasi terhadap 36 strain isolat pembentuk gaharu yang dilakukan, diketahui bahwa $F$. solani juga merupakan salah satu dari beberapa jenis cendawan pembentuk gaharu yang ditemukan.
Variasi genetik pada cendawan dapat diakibatkan karena beberapa faktor, antara lain adalah adanya mutasi, paraseksual, keragaman sitoplasma, reproduksi seksual (McDonald \& McDermott 1993; McDonald 1997). Berdasarkan hasil penjajaran, diketahui bahwa isolat 1 (Lombok Tengah) dan 2 (Alas) sama-sama memiliki kemiripan dengan $F$. solani yang menyerang tumbuhan berkayu, yaitu L. tulipifera dan C. acuminata.

Tabel 3. Analisis BLAST-n pada 12 amplikon PCR hasil sekuensing

\begin{tabular}{cllll} 
Sampel & \multicolumn{1}{c}{ Hasil BLAST (highest score) } & E-value & $\begin{array}{c}\text { Identitas } \\
(\%)\end{array}$ & No. aksesi \\
\hline Isolat1p1 & Fusarium solani, ITS1, 5.8S rRNA gene & 0.0 & 99 & KJ125735.1 \\
Isolat1p2 & Fusarium solani, ITS1, 5.8S rRNA gene & $3 \mathrm{e}^{-179}$ & 99 & KJ009328.1 \\
Isolat1p3 & Fusarium solani, TEF1 gene & 0.0 & 99 & KJ648657.1 \\
Isolat1p4 & Fusarium solani, TEF1 gene & 0.0 & 99 & KJ648642.1 \\
Isolat2p1 & Fusarium solani, ITS1, 5.8S rRNA gene & 0.0 & 99 & KM231798.1 \\
Isolat2p2 & Fusarium sp., ITS1, 5.8S rRNA gene & 0.0 & 99 & KP195151.1 \\
Isolat2p3 & Fusarium solani, TEF1 gene & 0.0 & 99 & JX886018.1 \\
Isolat2p4 & Fusarium solani, TEF1 gene & 0.0 & 99 & JX886018.1 \\
Isolat3p1 & Fusarium solani, ITS1, 5.8S rRNA gene & 0.0 & 99 & HQ379661.1 \\
Isolat3p2 & Fusarium sp., ITS1, 5.8S rRNA gene & 0.0 & 99 & KP195151.1 \\
Isolat3p3 & Fusarium solani, TEF1 gene & 0.0 & 99 & JX886018.1 \\
Isolat3p4 & Fusarium solani, TEF1 gene & 0.0 & 99 & HM770727.1 \\
\hline
\end{tabular}

\section{E. Analisis sekuen dengan menggunakan pohon filogenetik}

Untuk melakukan validasi terhadap hasil BLAST, maka analisis sekuen dengan menggunakan pohon filogenetik dilakukan. Analisis kekerabatan dengan menggunakan pendekatan ini memiliki tingkat keakuratan yang lebih tinggi dibanding BLAST (Brinkman \& Leipe, 2002). Pada penelitian ini, model jarak genetis menggunakan Jukes-Cantor dengan metode NeighborJoining untuk menghasilkan rooted tree. Model jarak genetis Jukes-Cantor mempertimbangkan secara seimbang laju substitusi tiap basa yang dibandingkan sehingga hubungan kekerabatan dipertimbangkan lebih baik (Kumar et al., 1994).

Analisis filogenetik dengan menggunakan primer ITS dan TEF-1 $\alpha$ menunjukkan kekerabatan tiga isolat cendawan yang diuji pada penelitian ini terhadap F. solani (Gambar 5 dan 6). 


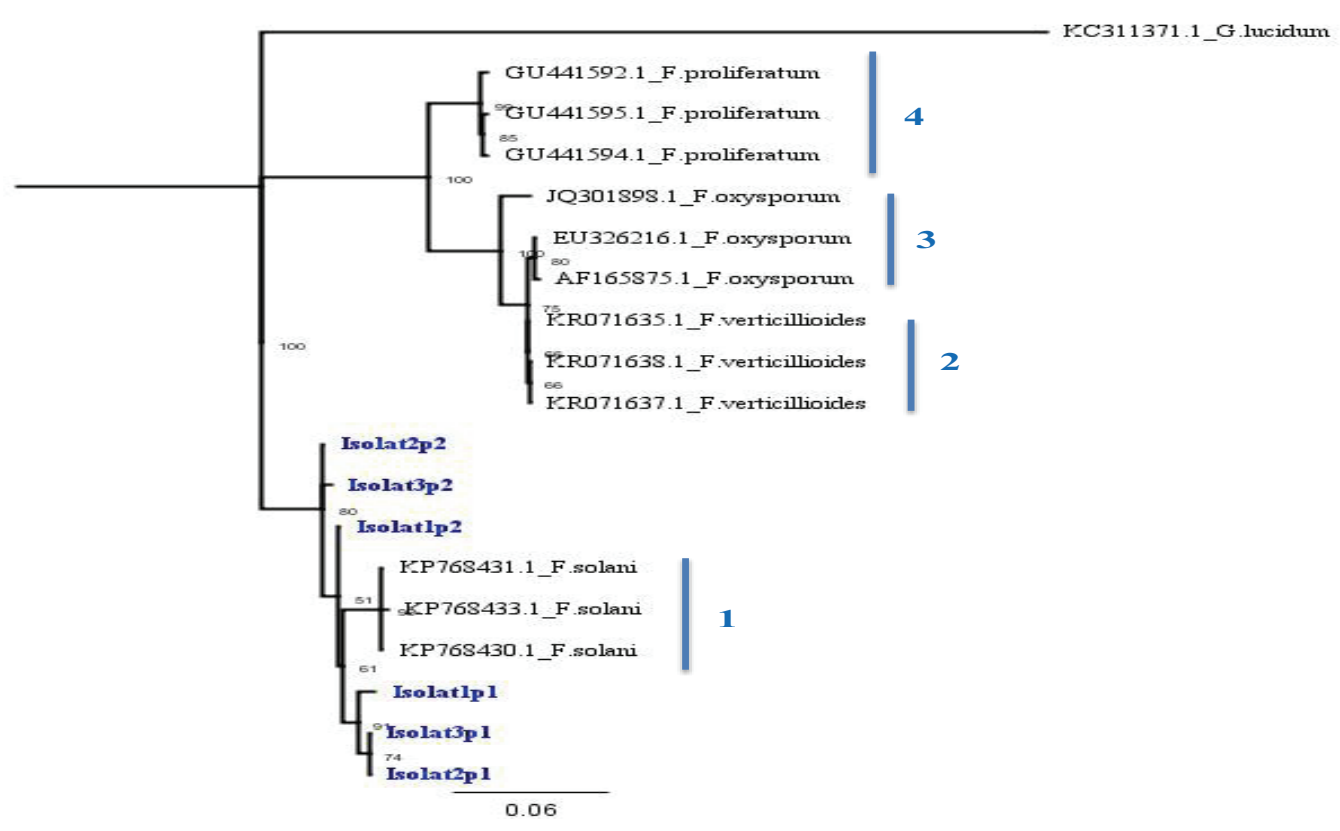

Gambar 5. Kekerabatan filogenetis tiga isolat cendawan dari Nusa Tenggara Barat menggunakan perbandingan sekuen ITS pada beberapa spesies Fusarium. Grup $1:$ F. solani, Grup $2:$ F. verticilloides, Grup 3 : F. oxysporum, Grup $4: F$. proliferatum. Sekuen Ganoderma lucidum digunakan sebagai outgroup Analisis filogenetik dilakukan dengan penjajaran MUSCLE diikuti dengan pengelompokan sekuen menggunakan Gblocks. Bootstrap menggunakan 100 ulangan.

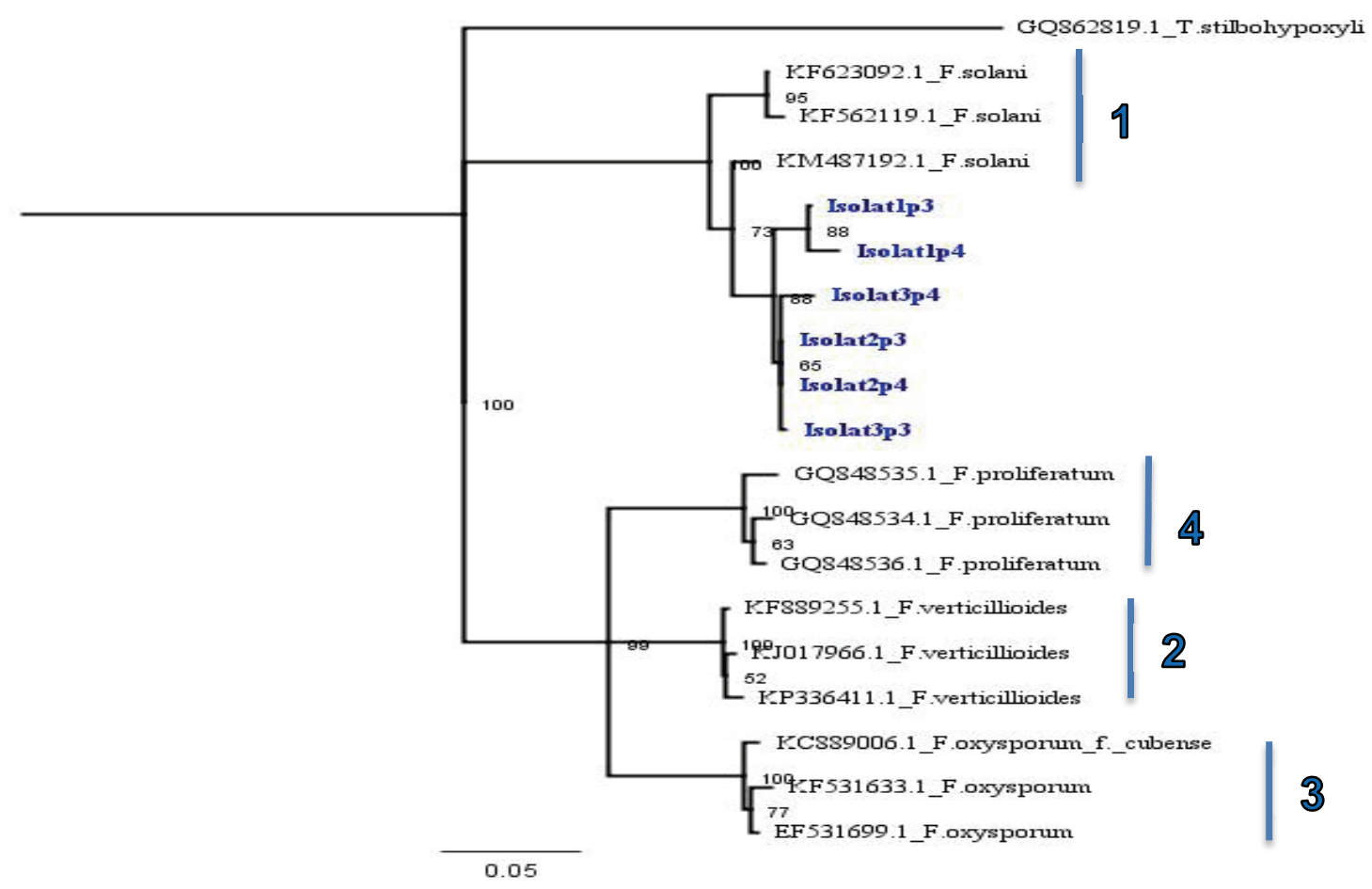

Gambar 6. Kekerabatan filogenetis tiga isolat cendawan dari Nusa Tenggara Barat menggunakan perbandingan sekuen TEF-1 $\alpha$ pada beberapa spesies Fusarium. Grup $1: F$. solani, Grup $2: F$. verticilloides, Grup $3: F$. oxysporum, Grup $4: F$. proliferatum. Sekuen Trichoderma stylbohypoxili digunakan sebagai outgroup. Analisis filogenetik dilakukan dengan penjajaran MUSCLE diikuti dengan pengelompokkan sekuen menggunakan Gblocks. Bootstrap menggunakan 100 ulangan. 
Tiga cendawan uji tersebut memiliki tingkat kepercayaan $51 \%$ dan $73 \%$ terhadap $F$. solani pada analisis menggunakan primer ITS dan TEF-1 $\alpha$. Hasil tersebut juga telah mengkonfirmasi ulang hasil analisis BLAST yang telah diperoleh. Secara umum, dalam analisis filogenetik terdapat 4 grup yaitu grup $1 F$. solani, grup 2:F. verticilloides, grup $3: F$. oxysporum, grup 4: F. proliferatum. Penjajaran sekuen dengan menggunakan MUSCLE dan Gblocks telah berhasil memberikan hasil pohon filogenetik yang akurat.

Berdasarkan pohon filogenetik dengan menggunakan primer 1 sekuen IST, ketiga isolat cendawan yang diuji secara evolusi memiliki kekerabatan lebih tua dari grup F. solani (Gambar 5). Sementara, F. solani merupakan tetua dari isolat yang diuji dengan menggunakan primer TEF-1 $\alpha$ (Gambar 6). Hasil tersebut dapat disimpulkan bahwa secara hipotesis sekuen ITS yang dimiliki tiga isolat cendawan yang diuji berasal dari tetua sebelum $F$. solani. Sedangkan, sekuen TEF-1 $\alpha$ pada ketiga cendawan uji tersebut kemungkinan berasal dari F. solani. Pada dasarnya, evolusi gen dapat terjadi secara individual pada dua spesies yang berdekatan (Brinkman \& Leipe, 2002).

\section{KESIMPULAN}

Pada penelitian ini, teknik PCR telah berhasil mengamplifikasi sekuen ITS dan TEF-1a. Analisis BLAST dan pohon filogenetik telah berhasil secara akurat mengidentifikasi tiga cendawan uji dalam penelitian ini sebagai $F$. solani. Kombinasi dari ketiga teknik tersebut dapat digunakan sebagai salah satu metode identifikasi spesies cendawan secara molekuler.

\section{UCAPAN TERIMA KASIH}

Penulis mengucapkan terima kasih sebesarbesarnya kepada Ibu Niyyah Fitranty atas bantuannya dalam penelitian ini, kepada seluruh anggota tim penelitian eksplorasi dan isolasi jamur pembentuk gaharu atas dukungan dan bantuan yang telah diberikan di lapangan maupun di laboratorium. Terima kasih juga kepada tim review dan mitra bestari sehingga tulisan ini dapat tersusun dengan baik.

\section{DAFTAR PUSTAKA}

Abd-Elsalam, K. A., Ibrahim, N. A., Abdel-Satar, M. A., Khalil, M. S., \& Verreet, J. A. (2003). PCR identification of Fusarium genus based on nuclear ribosomal-DNA sequence data. African Journal of Biotechnology, 2(4), 82-85.

Arif, M., Chawla, S., Zaidi, N. W., Rayar, J. K., Variar M., \& Singh, U. S. (2012). Development of specific primers for genus Fusarium and $F$. solani using rDNA subunit and transcription elongation factor (TEF-1 $\alpha$ ) gene. African Journal of Biotechnology, 11(2), 444-447.

Baldauf, S. L. (2003). Phylogeny for the faint of heart: a tutorial. TRENDS in Genetics, 19, 6.

Booth, C. (1971). The genus Fusarium. London: Commonwealth Mycological Institute.

Brinkman, F. S., \& Leipe, D. D. (2001). Phylogenetic analysis. Methods Biochem Anal., 43, 323-358. 
Edgar, R. C. (2004). MUSCLE: multiple sequence alignment with high accuracy and high throughput. Nucleic Acids Research, 32, 1792-1797.

Jalaluddin, M. (1977). A Useful Pathological Condition of Wood. Economic Botany, 31 (2), 222-224.

Kumar, S., Tamura, K., \& Nei, M. (1994). MEGA: Molecular Evolutionary Genetics Analysis software for microcomputers. Computer applications in the biosciences. CABIOS, 10, 189-191.

Kusuma, G. I. (2013). Identifikasi Cendawan Endofit Asal Tanaman Obat dan Penapisan Potensinya sebagai Antibakteri. Tesis. IPB (Bogor Agricultural University).

Legiastuti, T. S., \& Aminingsih, T. (2012). Identifikasi Cendawan Endofit Menggunakan Teknik Polymerase Chain Reaction. Jurnal Fitopatologi Indonesia, 2, 31-36.

McDonald, B. A. (1997). The population genetics of fungi: tools and techniques. Phytopathology, 87, 448-453.

McDonald, B. M., \& McDermott, J. M. (1993). Population genetic of plant pathogenic fungi, electrophoretic markers given unprecedented precision to analysis of genetic structure of population. Bio Science, 43, 311-319.

Mohamed, R., Jong, P. L., \& Zali, M. S. (2010). Fungal Diversity in Wouded Stems of Aquilaria malaccensis. Fungal Diversity, 43, 67-74.

Nugraheni, Y. M. M. A., Adisasmuko, S., \& Utomo, M. M. B. (2013). Isolasi dan Karakterisasi Fungi Pembentuk Gaharu Hasil Eksplorasi yang Berasal dari Empat Lokasi di Nusa Tenggara Barat. In A.P. Tampubolon, T. Rostiwati, B. Leksono, T.K. Waluyo, M. Turjaman, R. Effendi, \& S. Bustomi. (Eds.). Prosiding Seminar Nasional HHBK. 'Peranan Hasil Litbang Hasil Hutan Bukan Kayu dalam Mendukung Pembangunan Kehutanan (pp. 335-343). Mataram: Balai Penelitian Teknologi Hasil Hutan Bukan Kayu.

Nugroho, P. A. (2012). Identifikasi Molekuler Fusarium Penghasil Fumonisin yang Diisolasi dari Biji Jagung (Zea mays) di Tretep, Temanggung. Tesis. Universitas Gadjah Mada.

Orozco-Castillo, C., Chalmers, K. J., Waugh, R., \& Powell, W. (1994). Detection of Genetic Diversity and Selective Gene Introgression in Coffee using RAPD Markers. Theoretical and Applied Genetics, 87, 934940.

Premalatha, K., \& Kalra, A. (2013). Molecular Phylogenetic Identification of Endophytic Fungi Isolated from Resinous and Healthy Wood of Aquilaria malaccensis, A Red Listed and Highly Exploited Medicinal Tree. Fungal Ecology, 6, 205 - 211.

Prihatini, I. (2012). Identifikasi Jamur Endofit pada Tanaman Hutan Menggunakan Penanda Molekuler: Potensi Bagi Pengendalian Penyakit pada Tanaman Hutan. In A. Rimbawanto, B. Leksono, \& A.Y.P.B.C. Widyatmoko. (Eds.), Prosiding Seminar Nasional Bioteknologi Hutan. "Bioteknologi Hutan untuk Produktivitas dan Konservasi Sumber Daya Hutan” (pp. 109-118). Yogyakarta: Balai Besar Penelitian Bioteknologi dan Pemuliaan Tanaman Hutan.

Radian, F., Rianto, Masitoh, \& Yuaner. (2007). Identifikasi Tanaman dan Mikroba Pembentuk Gubal Gaharu di Kalimantan Barat. Agripura : Jurnal Ilmu-ilmu Pertanian Fakultas Pertanian Universitas Tanjungpura, 3(2), 424-433.

Roger A. J., Sandblom, O., Doolittle, W. F., \& Philippe, H. (1999). An evaluation of elongation factor 1 alpha as a phylogenetic marker for eukaryotes. Molecular Biology and Evolution, 16, 218-233.

Sambrook, J., \& Russell, D. W. (1989). Molecular cloning: A laboratory manual (3rd ed.). Cold Spring Harbor Laboratory Press.

Santella, R. M. (2006). Approaches to DNA/RNA Extraction and Whole Genome Amplification. Cancer Epidemiol Biomarkers Prev., 15(9), 1585-1587.

Santoso, E., Purwito, D., Pratiwi, Pari, G., Turjaman, M., Leksono, B., ... Siran, S. A. (2012). Master Plan Penelitian dan Pengembangan Gaharu Tahun 2013 2023. Pusat Penelitian dan Pengembangan Konservasi dan Rehabilitasi Badan Penelitian dan Pengembangan Kehutanan.

Schoch, C. L., Seifert, K. A., Huhndorf, S., Robert, V., Spouge, J. L., Levesque, C. A., ... Schindel, D. (2012). Nuclear ribosomal internal transcribed spacer (ITS) region as a universal DNA barcode marker for Fungi. In C. L. Schoch, K. A. Seifert, S. Huhndorf, V. Robert, J. L. Spouge, C. A. Levesque, W. Chen, \& Fungal Barcoding Consortium (Eds.), Proceedings of the 
National Academy of Sciences of the United States of America, 109, 6241-6246.

Sever, Z., Ivic, D., Kos, T., \& Miličević, T. (2012). Identification of Fusarium Species Isolated from Stored Apple Fruit in Croatia. Arh Hig Rada Toksikol, 63, 463-470.

Sitepu, I. R., Santoso, E., \& Turjaman, M. (2011). Identification of Eaglewood (Gaharu) Tree Species Susceptibility. Technical Report No. 1. R \& D Centre for Forest Conservation and Rehabilitation Forestry Research and Development Agency (FORDA) Ministry of Forestry Indonesia.

Sumarna, Y. (2012). Budidaya Jenis Pohon Penghasil Gaharu. Bogor: Badan Penelitian dan Pengembangan Kehutanan Pusat Litbang Produktivitas Hutan.

Talavera, G., \& Castresana, J. (2007). Improvement of phylogenies after removing divergent and ambiguously aligned blocks from protein sequence alignments. Syst. Biol., $56,564-577$.

Turjaman, M., Santoso, E., Sitepu, I. R., Subiakto, A., Pratiwi, Sri, S., ... Erry, P. (2009). Overview Pengembangan Gaharu. (ITTO PD425/06 REV.1 (1)). Seminar Gaharu I : Menuju Produksi Gaharu secara Lestari di Indonesia. Pusat Penelitian dan Pengembangan Hutan dan Konservasi Alam, Bogor. 